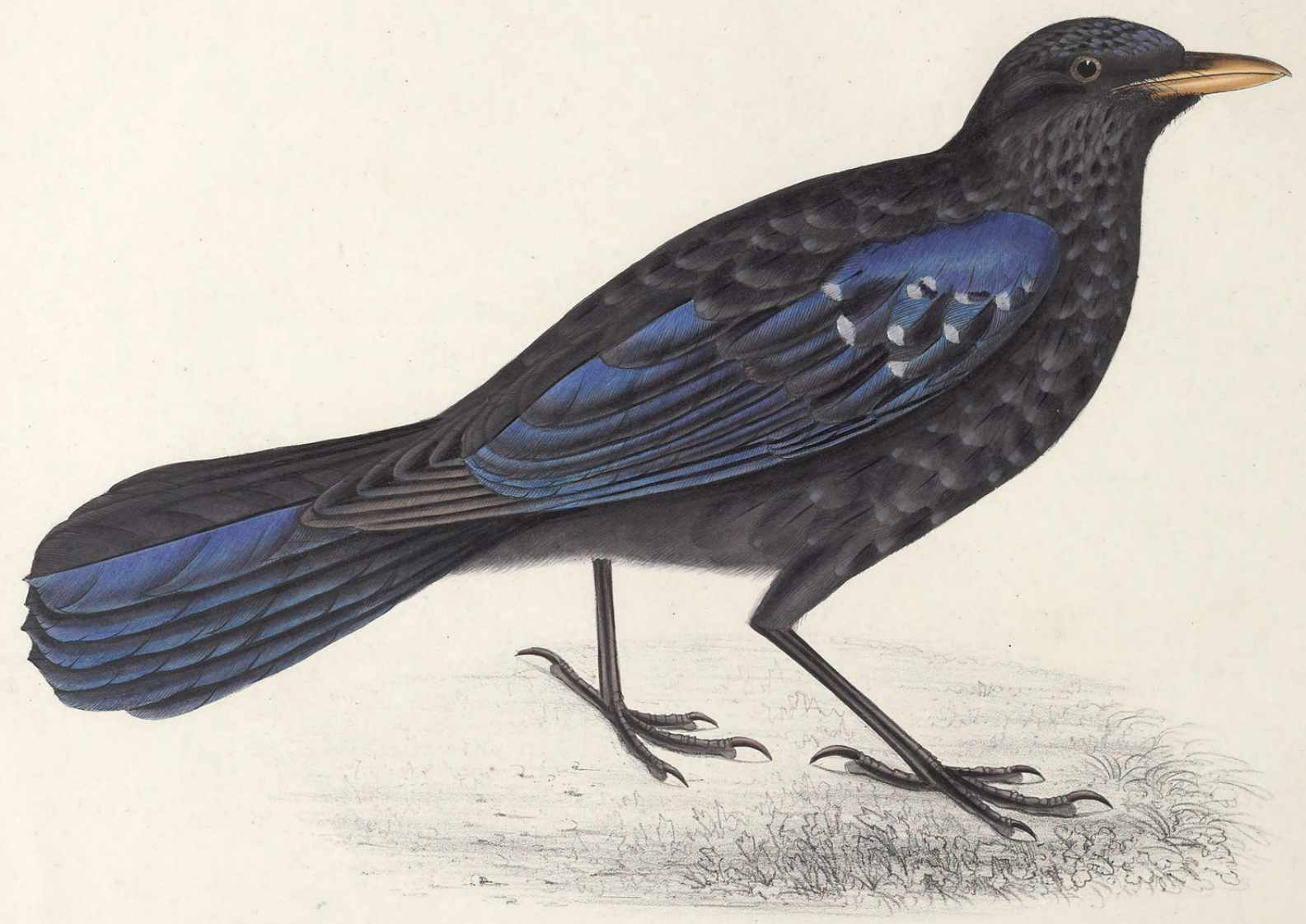

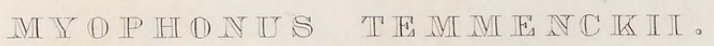




\section{TAB. XXI.}

\section{MYOPHONUS TEMMINCKII.}

Myoph. ater, azureo nitens, corporis in fronte plumis in medio metallicè splendentibus; abdomine fusco-atro; capite suprà in fronte regioneque carpali alarum lazulinis; tectricibus alarum parcè casio-albo maculatis; rostro favo.

Statura Myoph. Aavirostris (metallicus, Temm.), cui simillimus : differt rostro graciliori, colore splendidiore corporis caudæque, capitisque vertice lazulino.

THе present species fully equals in size the well-known Myophonus favirostris, and is adorned with plumage, if possible, still more intense and brilliant in colour. The principal characteristics, however, which distinguish the species before us from the Javanese bird, are its more slender beak, more lengthened tarsi, and a tail longer in proportion to the dimensions of the body.

The habitat of the two species differs widely:-for while the last-mentioned is distributed equally over the elevated regions of the Indian continent, the Myophomus favirostris, on the contrary, is confined to Java, Sumatra, and the islands in the Eastern Archipelago.

Mr. Shore notices in his MS., that the species is very abundant in the Himalayan mountains, where it is found equally in the warm regions of the Doon and the colder temperature of the Gurghwall,- that its native name is Kuljet, - and that its habits and actions, when on the ground, much resemble those of the English Blackbird. Further than this no distinct information of its history has hitherto been collected.

The general plumage is black with azure reflections; the forehead and shoulders bright lazuline blue; each feather on the back as well as on the sides of the neck and chest is glazed along its centre, which gives to those parts of the bird a metallic lustre; the quills are black; bill yellow with a dark culmen; the tarsi black.

The bird is figured of the natural size. 


\section{$2 \mathrm{BHL}$ Biodiversity Heritage Library}

Gould, John. 1831. "Myophonus temminckii [Tab. XXI]." A century of birds from the Himalaya Mountains -. https://doi.org/10.5962/p.323566.

View This Item Online: https://www.biodiversitylibrary.org/item/132967

DOI: https://doi.org/10.5962/p.323566

Permalink: https://www.biodiversitylibrary.org/partpdf/323566

\section{Holding Institution}

Smithsonian Libraries

\section{Sponsored by}

Biodiversity Heritage Library

\section{Copyright \& Reuse}

Copyright Status: Public domain. The BHL considers that this work is no longer under copyright protection.

This document was created from content at the Biodiversity Heritage Library, the world's largest open access digital library for biodiversity literature and archives. Visit BHL at https://www.biodiversitylibrary.org. 